\title{
KESIAPAN ASN MENGHADAPI MASA PENSIUN BERDASARKAN PANGKAT/GOLONGAN DAN JENIS KELAMIN SERTA IMPLIKASINYA TERHADAP KONSELING
}

\author{
Irene Mardova ${ }^{1)}$ \\ 1) Universitas Negeri Padang, Padang, Indonesia \\ E-mail: irenemardova90@gmail.com
}

\begin{abstract}
Abstrak. Masalah utama dalam penelitian ini adalah rendahnya kinerja dan meningkatnya kecemasan pada pegawai Aparatur Sipil Negara atau ASN yang akan memasuki masa pensiun. Tujuan dari penelitian ini adalah untuk memberikan gambaran tentang profil kesiapan Aparatur Sipil Negara dalam menghadapi pensiun berdasarkan pangkat/golongan dan jenis kelamin. Jenis penelitian ini adalah pendekatan kuantitatif deskriptif komparatif dengan model faktorial. Hasil penelitian menunjukkan ada perbedaan berdasarkan pangkat/golongan dan jenis kelamin. Layanan konseling diperlukan untuk mempersiapkan menghadapi masa pensiun.
\end{abstract}

Kata Kunci: Aparatur Sipil Negara; Pensiun; Layanan Konseling

\section{PENDAHULUAN}

Pensiun diartikan sebagai penarikan diri seseorang dari posisi atau pekerjaan atau dari kehidupan kerja aktif [1]. Sementara itu, masa pensiun dapat mengganggu kesehatan mental bagi individu yang tidak mempersiapkan diri dengan baik seperti reaksi kesedihan, masalah penyesuaian diri, kecemasan, serta depresi [2]. Pekerjaan tidak hanya sebagai usaha mencari penghidupan atau nafkah semata melainkan jauh lebih dalam maknya bagi individu yaitu eksistensi dan kebahagiaan. Seseorang yang bekerja merasa hidupnya lebih bermakna dan terhormat dari pada seseorang yang tidak bekerja.

Pekerjaan sangat menentukan posisi individu dalam pandangan masyarakat sehingga dalam hidupnya setiap individu berusaha memperoleh pekerjaan yang baik dan sesuai dengan minat serta kemampuannya. Sementara itu masa kerja seseorang terbatas, seiring bertambahnya usia biasanya performa kerja akan semakin menurun hingga tidak sanggup lagi untuk bekerja [3]. Menurunnya performa seseorang dalam melaksanakan tugas pekerjaannya hingga mangajukan diri untuk berhenti disebut dengan masa pensiun. Masa pensiun tersebut dialami oleh orang-orang yang bekerja sebagai karyawan pada perusahaan swasta, BUMN, maupun orang yang bekerja sebagai pelayan publik yaitu Aparatur Sipil Negara (ASN).

Aparatur Sipil Negara (ASN) adalah orang yang bekerja di bidang pelayanan publik dan dipekerjakan oleh pemerintah
Republik Indonesia. ASN bekerja melaksanakan tugas administratif berdasarkan undang-undang serta terbebas dari afiliasi kepentingan kelompok maupun organisasi tertentu. Selaku pegawai yang dipekerjakan pemerintah di bidang pelayanan publik, ASN memiliki peraturan yang membatasi usia kerja yang ditetapkan Undang-Undang (UU) dan Peraturan Pemerintah (PP). Adapun batas usia dalam melaksanakan pekerjaan bagi ASN yang memiliki jabatan fungsional ahli muda dan ahli pertama adalah usia 58 tahun [4], [5].

Berdasarkan peraturan perundang-undangan tersebut seorang ASN mengetahui masa kerjanya sebagai pelayan publik yang dipekerjakan oleh Negara. Oleh karena itu idealnya seorang ASN dapat mempersiapkan dirinya menghadapi masa pensiun terkait dengan pemenuhan kebutuhan hidup, penggunaan waktu luang, serta aktivitas yang akan dijalani selama masa pensiun [1]. Banyak aspek kebutuhan yang harus terpenuhi bagi seorang yang memasuki masa pensiun, yaitu tidak terbatas hanya pada pemenuhan sandang, pangan, dan papan tetapi mencakup kesehatan, kenyamanan, kebahagiaan, eksistensi diri, dan lain sebagainya yang mempengaruhi kesehatan mental. Hasil riset menunjukkan prevalensi pensiunan yang mengalami depresi sebesar $27,8 \%$, di mana gejala terbanyak terjadi pada pensiunan laki-laki [6].

Tingginya prevalensi depresi yang dialami oleh pensiunan dapat berakibat fatal berupa menurunnya dengan drastis kesehatan fisik hingga menyebabkan kematian. 
Sementara itu kesejahteraan fisik dan psikis para pensiunan merupakan tanggung jawab bersama terutama Negara yang telah mempekerjakannya dan telah diberikan amanat dalam Undang-undang untuk menjamin kesejahteraan pensiunan. Negara dengan segala sumber daya yang ada tentu tidak akan mampu menjangkau semuanya, oleh karena itu diperlukan peran berbagai komunitas dan profesi yang bergerak dibidang kesehatan mental untuk mewujudkan hal itu.

Konselor sebagai suatu profesi yang bergerak dalam bidang konseling dan kesehatan mental memiliki peran penting dalam mengatasi masalah ini. Adapun tujuan pelayanan konseling adalah untuk membantu membangun perencanaan, menumbuhkan reaksi efektif menghadapi masa pensiun, serta membantu calon pensiunan memasuki komunitas masyarakat yang berbeda dengan komunitas masyarakat selama ini digeluti. Bantuan konselor dapat menjaga performa kerja tetap baik sebelum pensiun, mengatasi kecemasan, serta mampu menyesuaikan diri dengan lingkungan yang selalu berubah.

Pegawai ASN pada masa-masa menjelang pensiun diharapkan tetap mampu melaksanakan tugas dan fungsinya secara baik karena berhubungan dengan pelayanan publik. Sementara itu hendaknya memiliki perencanaan yang matang sehingga tidak mengalami depresi memasuki masa pensiun. Namun kenyataan yang terjadi di salah satu kantor camat Kota Padang menunjukkan menurunnya secara drastis performa kerja pegawai ASN yang usianya menjelang masa pensiun seperti menurunnya motivasi kerja dan menurunnya kedisiplinan kerja. Selain itu tampak banyaknya pegawai ASN yang akan pensiun mengeluhkan kondisi kesehatan, menurunnya tenaga dan konsentrasi hingga menyebabkan menurunnya kualitas pelayanan publik.

Ada beberapa pertanyaan yang akan dijawab dalam penelitian ini, yaitu (1) bagaimana kesiapan pegawai ASN pada kantor Camat se-Kota Padang dalam menghadapi masa pensiun?, (2) bagaimana perbedaan kesiapan menghadapi pensiun berdasarkan pangkat/golongan dan jenis kelamin?, (3) bagaimana interaksi antara variabel pangkat/golongan dan jenis kelamin mempengaruhi kesiapan memasuki masa pensiun?, serta (4) bagaimana implikasinya terhadap pelayanan konseling.

Penelitian ini bermanfaat secara teori dan praktis. Secara teori penelitian ini dapat membuktikan asumsi-asumsi yang hidup dalam pikiran masyarakat terkait dengan performa pelayanan publik serta bagaimana memahami gejala tersebut. Selanjutnya secara praktis dapat menjadi masukan bagi pemerintah dalam merumuskan berbagai kebijakan tentang ASN, serta bagi profesi Konselor dapat mengembangkan treatment yang dapat mengatasi masalah tersebut pada ASN yang akan memasuki masa pensiun.

\section{METODE}

Jenis penelitian ini adalah penelitian kuantitatif dengan pendekatan deskriptif kuantitatif model faktorial. Subjek penelitian adalah pegawai ASN pada kantor Camat di sepuluh Kecamatan se-Kota Padang dengan usia 54-57 tahun yang berjumlah 62 orang. Pengumpulan data dilakukan dengan pengadministrasian angket dengan model skala likert yang mencakup lima aspek capaian kesiapan menjelang memasuki masa pensiun yaitu (1) keuangan, (2) kesehatan, (3) gaya hidup, (4) hubungan sosial, dan (5) mental-psikologis. Data dianalisis dengan teknik deskriptif kuantitatif dan uji varians dua jalur (anova two way).

\section{HASIL DAN PEMBAHASAN}

\section{A. Kesiapan Pegawai ASN Menghadapi Pensiun}

Hasil penelitian pada grafik I menunjukkan secara umum tingkat capaian kesiapan menghadapi masa pensiun pada pegawai ASN yang bekerja di kantor Camat se-Kota Padang adalah $83 \% \quad(n=62)$ yang berarti berada pada kategori siap. Apabila dicermati lebih rinci, yaitu (1) pada aspek keuangan, capaian kesiapan ASN adalah $80 \%$ yang berarti siap, (2) aspek kesehatan $82 \%$ yang berarti siap, (3) aspek gaya hidup $85 \%$ berarti sangat siap, (4) aspek hubungan sosial $86 \%$ berarti sangat siap, dan (5) aspek mental-psikologis $86 \%$ berarti sangat siap. Berdasarkan data tabel I tampak sebanyak $88,7 \%$ (55) responden berada pada kategori siap dan sisanya sebanyak $11,3 \%$ (7) berada pada kategori sangat siap.

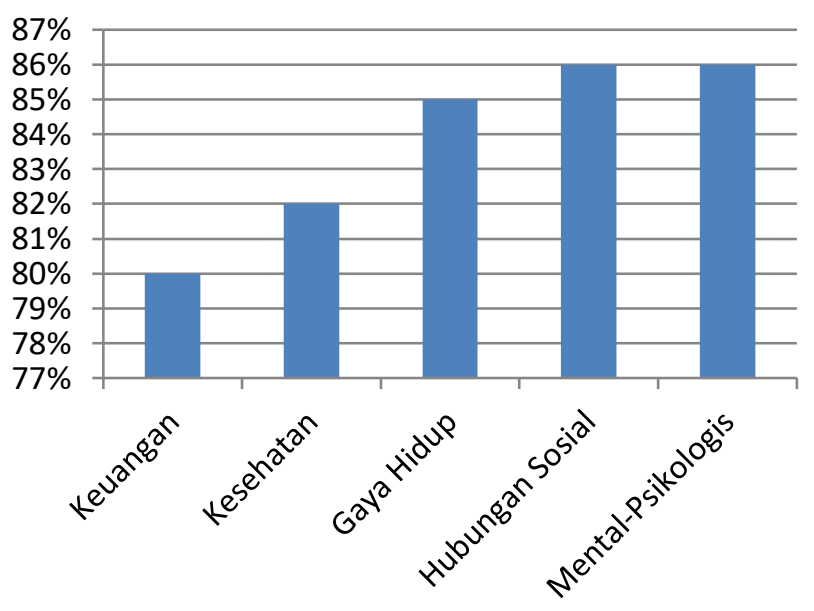

Grafik I. Tingkat Capaian Kesiapan Pegawai ASN Memasuki Masa Pensiun

Tabel I

Klasifikasi Kesiapan Pegawai ASN Memasuki Masa Pensiun

\begin{tabular}{cc}
\hline Klasifikasi & Jumlah/ \% \\
\hline Sangat Siap & $7 / 11,3$ \\
Siap & $55 / 88,7$ \\
Cukup Siap & - \\
Tidak Siap & - \\
Sangat Tidak Siap & - \\
\hline
\end{tabular}

B. Perbedaan Kesiapan Menghadapi Pensiun Berdasarkan Pangkat/Golongan dan Jenis Kelamin

Berdasarkan pangkat/golongan terungkap bahwa pegawai ASN golongan III memiliki rata-rata ketercapaian 82,59 hal itu lebih rendah dibandingkan dengan perolehan skor rata-rata pegawai ASN golongan IV sebesar 85,88. Berdasarkan jenis kelamin terungkap bahwa pada golongan III rata-rata capaian pegawai ASN laki-laki sebesar 79,67 hal ini jauh lebih rendah dibanding perolehan skor rata-rata pegawai 
ASN perempuan sebesar 85,77. Sementara itu pada pegawai ASN laki-laki golongan IV memperoleh capaian skor sebesar 84,75 yang berada di bawah perolehan skor pegawai ASN perempuan sebesar 87,00. Secara keseluruhan perbedaan capaian kesiapan pegawai ASN laki-laki lebih rendah $(82,21)$ dari pada pegawai ASN perempuan $(86,10)$, selengkapnya pada tabel II.

Capaian kesiapan memasuki pensiun berbeda berdasarkan pangkat/golongan maupun jenis kelamin, namun perbedaannya tidak begitu besar. Perempuan lebih siap menghadapi masa pensiun dari pada laki-laki, baik dari golongan III maupun golongan IV. Laki-laki pada golongan III tampak jauh kurang siap menghadapi pensiun dari pada laki-laki pada golongan IV.

Tabel II

Capaian Kesiapan Memasuki Pensiun

\begin{tabular}{|c|c|c|c|}
\hline Pangkat/Gol. & $\begin{array}{c}\text { Jenis } \\
\text { Kelamin }\end{array}$ & Rata-rata & $\mathbf{n}$ \\
\hline \multirow{3}{*}{ III } & Laki-Laki & 79.67 & 24 \\
\hline & Perempuan & 85.77 & 22 \\
\hline & Total & 82.59 & 46 \\
\hline \multirow{3}{*}{ IV } & Laki-Laki & 84.75 & 8 \\
\hline & Perempuan & 87.00 & 8 \\
\hline & Total & 85.88 & 16 \\
\hline \multirow{3}{*}{ Total } & Laki-laki & 82.21 & 32 \\
\hline & Perempuan & 86.10 & 30 \\
\hline & Total & 83.44 & 62 \\
\hline
\end{tabular}

C. Perbedaan Pangkat/Golongan \& Jenis Kelamin serta Pengaruhnya terhadap Kesiapan Menghadapi Pensiun

Hasil penelitian menunjukkan pada umumnya pegawai Aparatur Sipil Negara (ASN) di kantor Camat pada sepuluh Kecamatan Kota Padang memiliki kesiapan yang baik dalam menghadapi masa pensiun. Kesiapan dapat ditinjau dari lima aspek kehidupan yaitu keuangan, kesehatan, gaya hidup, hubungan sosial, dan kondisi mental-psikologis. Kesiapan ini tidak terlepas dari kemampuan pemerintah dalam memenuhi kebutuhan gaji pegawai seperti tunjangan ataupun bentuk lainnya sehingga kebutuhan pokok akan pangan, sandang, dan papan umumnya sudah terpenuhi.

Pegawai ASN yang akan pensiun pada golongan III memiliki kesiapan lebih rendah dibanding pegawai ASN yang akan pensiun pada golongan IV. Hal ini sejalan dengan besaran pendapatan yang diterima oleh pegawai ASN di mana pendapatan pegawai golongan IV lebih besar. Selain itu jabatan yang dimiliki seseorang selama aktif bekerja akan mempengaruhi penyesuaian dirinya pada saat memasuhi masa pensiun. Jabatan menimbulkan penghormatan dari orang lain yang menyebabkan hidup menjadi lebih bermakna, hal ini dibuktikan dengan adanya hubungan yang erat antara harga diri dengan makna hidup pada pegawai yang akan memasuki masa pensiun [7]. Adanya pendapatan yang lebih memadai mempengaruhi kesiapan dalam perencanaan keuangan di masa pensiun, termasuk pemenuhan pada kebutuhan perumahan dan gaya hidup.
Pegawai ASN laki-laki tampaknya memiliki kesiapan yang lebih rendah apabila dibandingkan pada pegawai ASN perempuan, baik pada golongan III maupun golongan IV. Laki-laki memang sejatinya merupakan tulang punggung keluarga, apalagi semakin banyak kepala keluarga yang pensiun dalam keadaan anak-anak masih kuliah serta kurangnya dukungan pendapatan dari isteri yang biasanya sebagai ibu rumah tangga. Tingginya kesiapan perempuan menghadapi masa pensiun sejalan dengan besaran tanggung jawab yang dipikulnya dalam keluarga, sebagai seorang isteri dalam rumah tangga biasanya isteri berperan sebagai penunjang finansial keluarga, oleh karena itu secara psikoilogis tidak begitu cemas.

Penelitian sebelumnya mengungkapkan hal yang berbeda, bahwa gender maskulin memiliki kesiapan menghadapi masa pensiun apabila dibandingkan dengan gender feminim [8], namun perbedaannya dengan penelitian ini adalah setting penelitian, yaitu karyawan BUMN. Oleh karena itu perlu adanya penelitian yang membandingkan kesiapan menghadapi pensiun antara ASN dengan pegawai BUMN. Karakteristik pekerjaan yang ada di lingkungan pemerintah memang berbeda dengan karakteristik pekerjaan di BUMN, hal ini dapat menjadi faktor penentu kesiapan seseorang pegawai atau karyawan dalam menghadapi masa pensiun.

Perubahan hidup disatu sisi dapat menyebabkan gangguan pada mental-psikologis, memasuki masa pensiun merupakan fase perubahan hidup yang sangat menentukan. Perubahan dapat menyebabkan stres dan depresi apabila tidak memiliki ketahanan terhadap perubahan yang terjadi. Penelitian terdahulu menemukan bahwa tingkat stres pegawai ASN pada pangkat/golongan yang tinggi cenderung lebih rendah serta memiliki kemampuan ketahan diri yang lebih baik [9]. Berdasarkan fakta ini, tampaknya ada kecenderungan keterkaitan antara kesuksesan menapaki jenjang karir dalam birokrasi dengan kesiapan memasuki masa pensiun, terutama dari aspek keuangan dan mental-psikologis, hal ini didukung oleh temuan penelitian ini bahwa baik laki-laki dan perempuan memiliki kesiapan memasuki pensiun yang lebih baik pada golongan IV dibanding golongan III, namun memerlukan penelitian lanjutan untuk membuktikannya.

Para pensiunan sebagai warga Negara yang telah menyempurnakan baktinya memiliki hak untuk dibekali dalam perkembangannya di usia tua, masalah yang sering terabaikan adalah aktualisasi diri yang akhirnya berpengaruh pada kesehatan fisik. Program-program pembekalan keterampilan tertentu sangat relevan pada pegawai yang akan memasuki masa pensiun, hal ini dibuktikan dengan adanya tanggapan yang positif dari pegawai ASN yang akan pensiun tentang program pembekalan yang diselenggarakan dan berpengaruh pada kesiapan menghadapi pensiun [10].

\section{Implikasinya terhadap Konseling}

Konseling merupakan layanan yang diberikan kepada individu maupun kelompok agar berkembang potensinya secara maksimal dan mampu menjalankan kehidupan seharihari [11]. Selain itu melalui layanan konseling individu mampu mewujudkan kemandirian dan menyesuaikan diri 
dengan lingkungan yang selalu berubah [12]. Fungsi konseling adalah untuk pencegahan terhadap potensi terjadinya masalah, pengentasan apabila telah mengalami masalah, dan pengembangan untuk meningkatkan potensi diri individu sehingga memiliki kemandirian dan pengendalian diri [13].

Konselor sebagai pemberi layanan konseling merupakan tenaga terampil dan profesional yang menguasai kaidah, teknik, dan praktek konseling. Sebagai tenaga profesional, lingkup kerja konselor tidak hanya di lembaga pendidikan seperti sekolah melainkan meliputi perguruan tinggi, dunia usaha dan industri [14], selain itu juga diperlukan di rumah sakit, lembaga kesejahteraan sosial, dan lembaga pemerintahan lainnya. Pelayanan konseling meliputi bidang pribadi, sosial, karir, pekerjaan, keluarga, dan agama [13]. Kompetensi yang harus dimiliki konselor untuk mampu memberikan pelayanan konseling meliputi kompetensi pedagogi, personal, sosial, dan profesional [15]. Kualitas pribadi konselor menjadi instrumen utama yang menentukan keberhasilan layanan konseling [16].

Konseling untuk pegawai ASN yang akan menghadapi masa pensiun merupakan suatu yang sangat penting, hal ini bertujuan untuk menjaga performa kerja dan kesiapan mental dalam menghadapi masa pensiun. Kehidupan yang berubah bagi seorang ASN yang memasuki masa pensiun tidak mudah, banyak aspek yang harus dipersiapkan, oleh karena itu dibutuhkan bimbingan dan arahan oleh tenaga ahli dan terampil seperti konselor. Dukungan psikologis dan arah pengembangan karir yang tepat dapat meningkatkan kebahagiaan hidup di masa tua, karena eksistensi diri sudah menjadi kebutuhan utama.

\section{KESIMPULAN}

Hasil penelitian menunjukkan pegawai ASN di sepuluh Kecamatan Pemerintah Kota Padang sudah memiliki kesiapan yang baik dalam menghadapi masa pensiun, hal ini terlihat dari capaian kesiapan yang baik dari segi perencanaan keuangan, kondisi kesehatan, pola gaya hidup, hubungan sosial, dan kondisi mental-psikologis. Selain itu terdapat perbedaan kesiapan berdasarkan pangkat/golongan dan jenis kelamin. Semakin tinggi pangkat/golongan maka semakin tinggi kesiapan seorang pegawai ASN dalam menghadapi masa pensiun. Pegawai ASN laki-laki memiliki kesiapan yang lebih rendah dibanding pegawai ASN perempuan.

Pelayanan konseling sangat penting untuk menunjang keefektifan hidup dan kebahagiaan di hari tua, meliputi perencanaan keuangan, karir, sosial, dan kesehatan mentalpsikologis. Pelayanan konseling pada pegawai ASN yang akan memasuki masa pensiun berfungsi untuk pencegahan, pengentasan, dan pengembangan.

\section{DAFTAR PUSTAKA}

[1] Mukku, S. S. R., Harbisettar, V., \& Sivakumar, P. T. (2018). Psychological Morbidity after Job Retirement: A Review. Asian Journal of Psychiatry, 37, 58-63.

[2] Laly, P. (2007). Identity and Athletic Retirement: A Prospecti Study. Psychology of Sport and Exerscise, 8(1), 85-99.

[3] Reyers, M. (2018). Perceptions of Retirement Adequacy: Evidance from South Africa. Journal of Financial Counseling and Planning, 29(2).

[4] Undang-Undang Aparatur Sipil Negara Nomor 5 Tahun 2014 tentang Pokok-Pokok Kepegawaian (2014). Republik Indonesia.

[5] Peraturan Pemerintah Republik Indonesia Nomor 21 Tahun 2014 tentang Pemberhentian Pegawai Negeri Sipil (2014). Republik Indonesia.

[6] Putri, F. D., Yarnis, A., \& Syamsir, E. (2014). Prevalensi Depresi pada Pensiunan Pegawai Negeri Sipil yang Mengambil Dana Pensiun di Bank BTPN Cabang M. Yamin Padang. JurnalKesehatan Andalas, 4(2).

[7] Setyarini, R., \& Atamimi, N. (2011). Self-Esteem dan Makna Hidup pada Pensiunan Pegawai Negeri Sipil (PNS). Jurnal Psikologi, 38(2), 176-184.

[8] Safitri, B. R. (2013). Kesiapan Menghadapi Masa Pensiun di Tinjau dari Gender Karyawan. Jurnal Ilmiah Psikologi Terapan, 1(2), 191-204

[9] Hidayat, D., Zamralita, Z., \& Nilnawati, N. (2006). Resiliensi dan Tingkat Stres Pada Masa Persiapan Pensiun. Phronesis, 8(6), 50 70.

[10] Saputra, H. R., \& Sagala, E. J. (2016). Pengaruh Program Persiapan Pensiun Terhadap Kesiapan Pensiun Karyawan di PT Krakatau Steel (Persero) TBK. In e-Proceeding of Manajemen Telkom University (Vol. 3, pp. 2991-2998). Bandung: Universitas Telkom.

[11] Prayitno. (2017). Konseling Profesional yang Berhasil: Layanan dan Kegiatan Pendukung (1st ed.). Jakarta: Rajawali Pers.

[12] Willis, S. S. (2004). Konseling Individual: Teori dan Praktek. Bandung: Alfabeta.

[13] Marjohan, M., Asri, Z., Gusraredi, G., Ifdil, I., \& Afriani, N. (2012). Biografi Keilmuan Prayitno dalamRanah Konseling \& Pendidikan. Padang: UNP Press.

[14] Ardimen, A. (2018). Visi Baru Konselor Sekolah dalam Rangka Meningkatkan Kualitas Layanan Pendidikan di Sekolah dan Madrasah. Jurnal Konseling Indonesia, 4(1), 22-29.

[15] Permendiknas No. 27 Tahun 2008 tentang Standar Kualifikasi Akademik Kompetensi Konselor (2008). Republik Indonesia.

[16] Putri, A. (2016). Pentingnya Kualitas Pribadi Konselor dalam Konseling untuk Membangun Hubungan Antar Konselor dan Konseli. Jurnal Bimbingan Konseling Indonesia, 1(1), 10-13. 